\title{
THE USE OF $\beta$-LACTAMASES IN THE CLINICAL LABORATORY
}

\author{
S. W. B. Newsom AND BRIDGET M. WALSINGHAM \\ Sims Woodhead Memorial Laboratory, Papworth Hospital, Cambridge
}

THE use of $\beta$-lactamases (penicillinases) to destroy penicillin in culture media (Harper, 1943) is well established. These enzymes can also be used to destroy penicillin in body fluids to allow the assay of another antibiotic, such as streptomycin. A chance observation (Newsom, 1967) led to the realisation that some commercially available enzymes destroyed cephaloridine, methicillin, and cloxacillin. Many more $\beta$-lactam antibiotics and $\beta$-lactamases are now available and this investigation was undertaken to study them all. The commercially available "penicillinases" are filtrates of cultures of Bacillus species, usually Bacillus cereus or B. licheniformis. The activity of the different preparations is very variable and the situation is more confused because the units used by the makers to express it are nearly all calculated by different methods.

The zinc-dependent $\beta$-lactamase II from $B$. cereus, strain $569 / \mathrm{H}$ (Kuwabara and Abraham, 1967) and the $\beta$-lactamases made by some enterobacteria (Jack and Richmond, 1970), especially Enterobacter cloacae (Fleming, Goldner and Glass, 1963), preferentially destroy cephalosporins. Crude enzymes were therefore made from some enterobacteria and from a highly carbenicillinresistant strain of Pseudomonas aeruginosa (Newsom, Sykes and Richmond, $1970)$ to compare their activity with that of the bacillus enzymes.

\section{MATERIALS AND METHODS}

The antibiotics tested fell into three groups. The " penicillinase-sensitive " group included: benzylpenicillin, ampicillin, carbenicillin, amoxycillin, and BRL 2288-a carbenicillin-like compound. The "penicillinase-resistant" group included: methicillin, cloxacillin, flucloxacillin, Magnapen (flucloxacillin and ampicillin), and Ampiclox (cloxacillin and ampicillin). The cephalosporin group included cephaloridine, cephalexin, and cephalothin. The antibiotic stock solutions were stored at $-20^{\circ} \mathrm{C}$ and working dilutions of 5,50 , and $500 \mu \mathrm{g}$ per ml were made in horse serum.

Enzymes. Bacillus-enzyme preparations were obtained from the following firms: Whatman Biochemicals Ltd, Springfield Mill, Maidstone $(\beta$-lactamase $1+11)$; Riker Laboratories, Loughborough (" Neutrapen "); Baltimore Biological Laboratories, York House, Empire Way, Wembley (penicillinase concentrate); Difco Laboratories, Central Avenue, East Molesey, Surrey ("Penase " concentrate); AVM Pharmaceuticals Ltd, PO Box 79, Wrexham, Denbigh (penicillinase); Wellcome Reagents Ltd, Beckenham, Kent (penicillinase), and KochLight Laboratories, Colnbrook, Bucks (penicillinase). The Whatman, Riker, and AVM products were freeze dried; the others were liquid. The Riker enzyme was made for administration to man, the AVM for addition to milk and dairy products, and the others for

Received 23 June 1972; accepted 12 July 1972.

J. MED. MICROBIOL. - VOL. 6 (1973) 
laboratory use only. Crude enzyme extracts were made by us from strains of Enterobacter aerogenes, Klebsiella aerogenes, Escherichia coli, and the aforementioned strain of $P$. aeruginosa, which were all obtained from routine laboratory cultures. The organisms were grown

TABLE I

$\beta$-lactamases tested-specifications and results of iodometric assay

\begin{tabular}{|c|c|c|c|c|}
\hline \multirow[b]{2}{*}{ Make } & \multicolumn{2}{|c|}{ Information from makers } & \multicolumn{2}{|c|}{$\begin{array}{l}\text { Results of iodometric assay; } \\
\mu \text { moles of indicated antibiotic } \\
\text { destroyed per hr }\end{array}$} \\
\hline & Unit specification & $\begin{array}{l}\text { Concentration (units); } \\
\text { organism of origin }\end{array}$ & Benzylpenicillin & Cephaloridine \\
\hline $\begin{array}{l}\text { Whatman } \\
\text { Biochemicals }\end{array}$ & $\begin{array}{l}1 \text { unit destroys } 1 \mu \text { mole per } \mathrm{hr} \\
\text { at } p \mathrm{H} 7.0 \text { and } 30^{\circ} \mathrm{C}\end{array}$ & $\begin{array}{l}50,000 \text { units per vial; } \\
\text { B. cereus }\end{array}$ & 28,000 per vial & 480 per vial \\
\hline Riker & $\begin{array}{l}1 \text { unit destroys } 1 \text { unit of } \\
\text { benzylpenicillin per min. at } \\
25^{\circ} \mathrm{C} \text { and } p \mathrm{H} 7.0\end{array}$ & $\begin{array}{l}800,000 \text { units per vial; } \\
\text { B. cereus }\end{array}$ & 100,000 per vial & 730 per vial \\
\hline $\begin{array}{l}\text { Baltimore } \\
\text { Biological } \\
\text { Laboratories }\end{array}$ & $\begin{array}{l}1 \text { Kersey unit destroys } 0.39 \text { unit } \\
\text { benzylpenicillin at } 30^{\circ} \mathrm{C} \text { and } \\
p \mathrm{H} 7.0\end{array}$ & $\begin{array}{l}1,000,000 \text { units per } \mathrm{ml} ; \\
\text { B. cereus }\end{array}$ & 5400 per $\mathrm{ml}$ & 64 per $\mathrm{ml}$ \\
\hline Difco & Kersey unit (as above) & $\begin{array}{l}2,000,000 \text { units per } \mathrm{ml} ; \\
?\end{array}$ & 2600 per $\mathrm{ml}$ & 40 per $\mathrm{ml}$ \\
\hline AVM & $\begin{array}{l}1 \text { unit destroys } 2-3 \text { units } \\
\text { benzylpenicillin at } 37^{\circ} \mathrm{C} \text { and } \\
p \mathrm{H} 7.0\end{array}$ & $\begin{array}{l}100,000 \text { units per vial; } \\
\quad \text { B. cereus }\end{array}$ & 1200 per vial & 96 per vial \\
\hline Wellcome & $\begin{array}{l}1 \text { unit destroys } 1 \text { unit of } \\
\text { benzylpenicillin }\end{array}$ & $\begin{array}{l}100,000 \text { units per } \mathrm{ml} \\
\text { B. cereus }\end{array}$ & 52 per $\mathrm{ml}$ & 0 \\
\hline Koch-Light & $\begin{array}{l}1 \text { unit destroys } 1 \text { unit of } \\
\text { benzylpenicillin }\end{array}$ & $\begin{array}{l}100,000 \text { units per } \mathrm{ml} \\
\quad B . \text { licheniformis }\end{array}$ & 280 per ml & 0 \\
\hline Papworth 1 & $\ldots$ & $\ldots ;$ Klebsiella & 2000 per $\mathrm{ml}$ & 1680 per ml \\
\hline 2 & $\ldots$ & ...; Enterobacter & 1600 per ml & 1200 per $\mathrm{ml}$ \\
\hline 3 & $\ldots$ & ..; $;$ Esch. coli & 10 per ml & 0 \\
\hline 4 & $\cdots$ & ․; & 660 per $\mathrm{ml}$ & 112 per $\mathrm{ml}$ \\
\hline
\end{tabular}

for $18 \mathrm{hr}$ on 10-in. assay dishes containing nutrient agar. The growth was resuspended in $40 \mathrm{ml}$ of distilled water and disrupted for $5 \mathrm{~min}$. in an ultrasonic cell disintegrator (Dawe Instruments Ltd). The extract was centrifuged at 15,000 r.p.m. for $5 \mathrm{~min}$. and the supernatant fluid was sterilised by passing it through a $0 \cdot 22-\mu \mathrm{m}$ membrane-filter. The freeze-dried commercial enzymes were reconstituted in $2 \mathrm{ml}$ of phosphate-buffered saline, $p \mathrm{H} 5 \cdot 9$, which was used as buffer throughout. Stock solutions of enzymes were stored at $-70^{\circ} \mathrm{C}$. Dilutions of 1 in 10, 1 in 100, and 1 in 1000 of the enzymes were made in buffered saline. 
The biochemical activity of the enzymes was estimated by the iodometric method of Perret (1954). Benzylpenicillin and cephaloridine were used as substrates, and the calculations took account of the fact that cephalosporins react with half as much iodine as do the penicillins. The results are expressed as $\mu$ moles of substrate destroyed per hour.

The biological activity of the enzymes was measured by mixing $0.05-\mathrm{ml}$ volumes of enzyme dilutions and of antibiotics in a "Microtiter" (Cooke) tray and assaying the residual antibiotic after $1 \mathrm{hr}$ at room temperature $\left(18^{\circ} \mathrm{C}\right)$. Some additional tests were done after shorter reaction times. The whole of each antibiotic-enzyme mixture was transferred to a well in a 10-in.-square dish containing nutrient agar overlayed with a standardised suspension of Sarcina lutea no. NCIB8553 (no. ATCC9341) in agar (Grove and Randall, 1955). Antibiotic controls were included. The results were scored as positive only when there was complete destruction of the antibiotic; inhibition zones of reduced size were ignored. Streptomycin was assayed in the presence of penicillins and $\beta$-lactamases by a similar method, but with B. subtilis var. globigii no. NCTC10073 as the test organism.

\section{RESULTS}

Table I shows the results of the biochemical assay of the enzymes and compares these with the data provided by the makers. The Whatman enzyme was defined in $\mu$ moles of substrate destroyed per hour measured iodometrically, the Difco and Baltimore Biologicals enzymes were in Kersey units (Kersey et al., 1955) and the others in units defined by their makers. The Baltimore Biologicals enzyme had been received 1 yr before testing, was stored in accordance with the makers' instructions, and was said to have an indefinite shelf life; the results of the iodometric assays were 75 per cent. lower than those done when this enzyme was first received, but the enzyme was still very active. The results of the jodometric assays of all the enzymes showed that there was a wide range of activity, and that the "Gram-negative " enzymesexcept the escherichia enzyme-were highly active against cephaloridine.

The results of the biological tests for destruction of penicillinase-sensitive penicillins are seen in table II. The term "penicillinase sensitive" is used loosely here, for it is meant to refer to the sensitivity of the antibiotics to the amounts of penicillinase produced in vivo by staphylococci. The enzymes all destroyed $500 \mu \mathrm{g}$ per ml of benzylpenicillin, although the Esch. coli, Wellcome, and Koch-Light enzymes acted on this concentration of antibiotic only neat or at a dilution of 1 in 10 . The action of the enzymes on other members of the group was very similar to that on benzylpenicillin. The enterobacterial enzymes were slightly less active against ampicillin, the Wellcome enzyme was less active against carbenicillin, and the pseudomonas enzyme was predictably most active against carbenicillin.

Table III records the action of the enzymes on the " penicillinase-resistant" penicillins. The enzymes did not destroy these as well as the previous group. The weaker ones could not destroy $500 \mu \mathrm{g}$ per $\mathrm{ml}$ of cloxacillin or flucloxacillin. The strongest enzymes destroyed these antibiotics at a dilution of 1 in 100 . Cloxacillin and flucloxacillin were equally resistant to destruction; Ampiclox and Magnapen - containing half the amount of cloxacillin and flucloxacillinwere less resistant and methicillin, although the most readily destroyed was considerably more resistant than benzylpenicillin. 


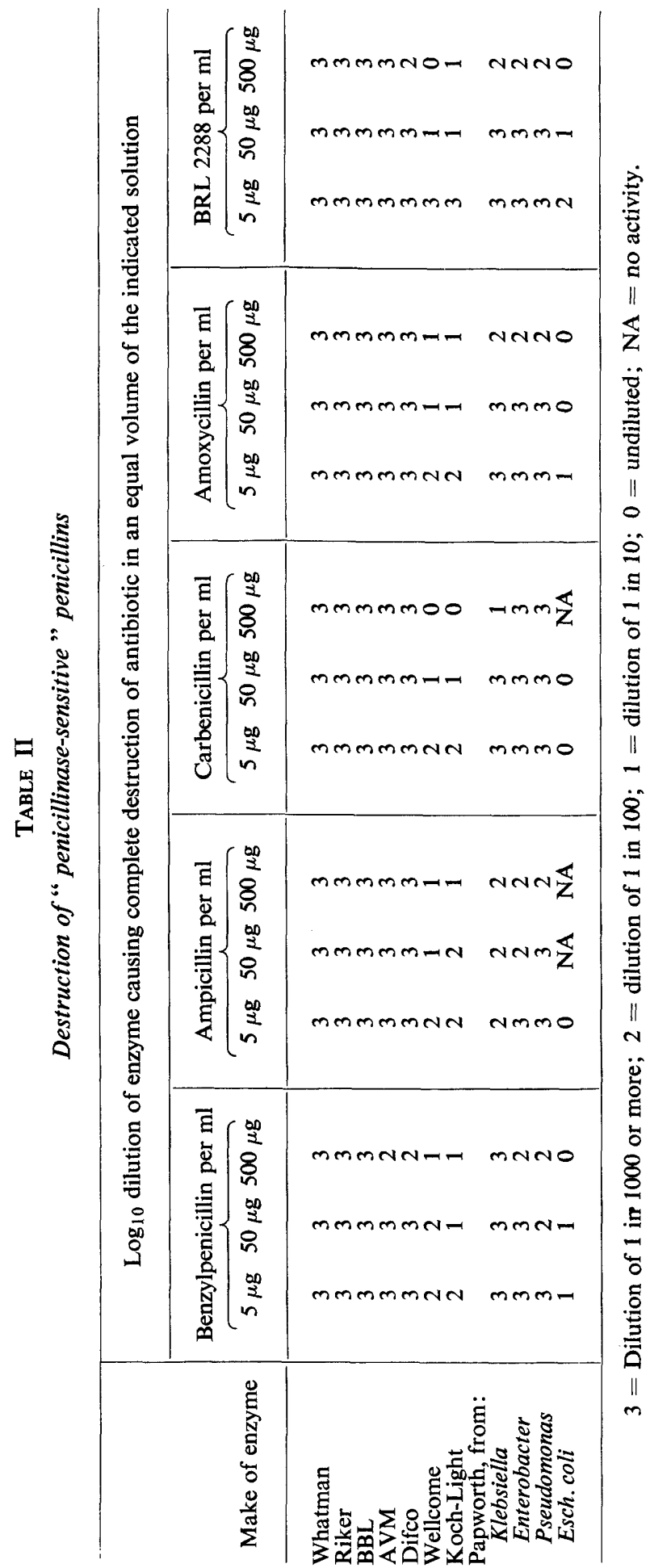


THE USE OF $\beta$-LACTAMASES

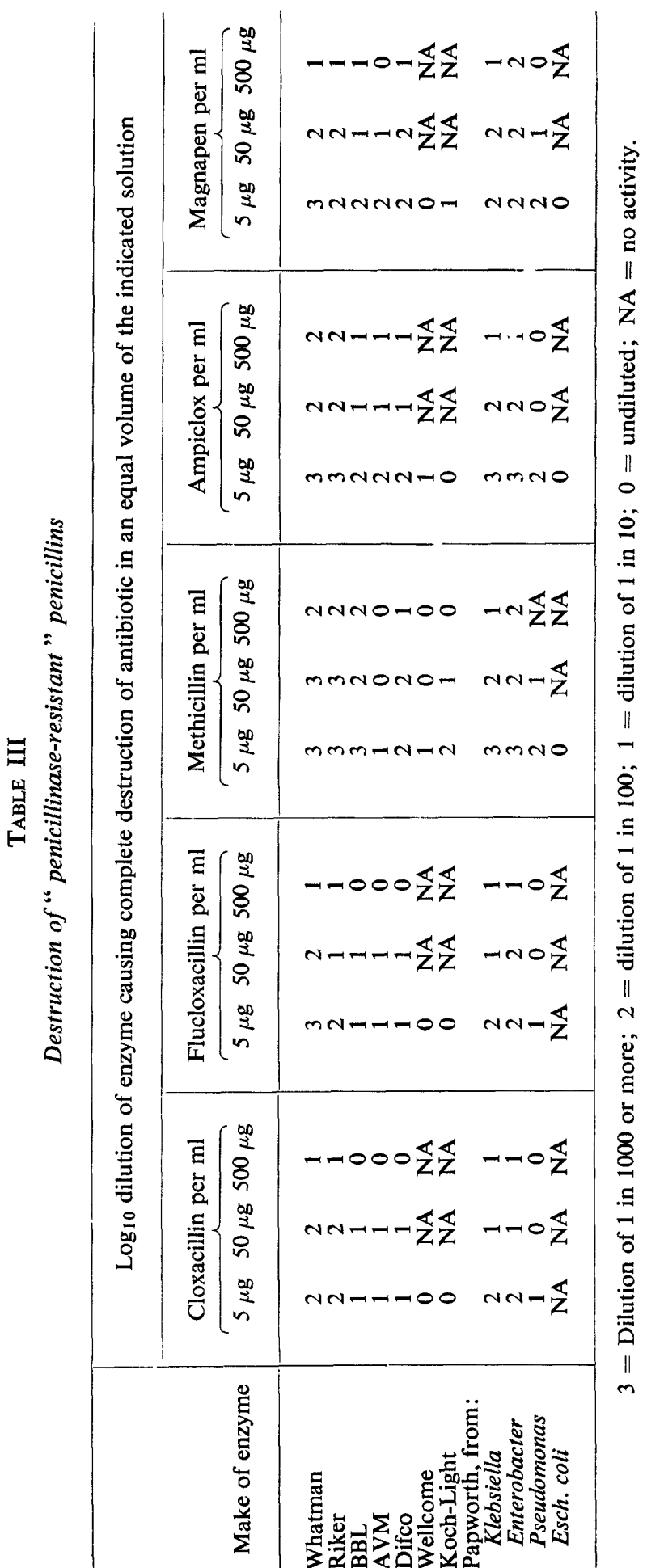


The action of the enzymes on the cephalosporins is seen in table IV. The ranges of enzyme activity and substrate resistance are greater than in the previous experiments. The weaker enzymes could not destroy $5 \mu \mathrm{g}$ per $\mathrm{ml}$ of cephalexin, and only two of the bacillus enzymes destroyed $500 \mu \mathrm{g}$ per $\mathrm{ml}$ of this antibiotic. The klebsiella and enterobacter enzymes had the greatest effect on cephalexin, which correlates well with the iodometric assay. Cephaloridine was the most easily destroyed and cephalothin was more resistant to destruction by the enzymes.

TABLE IV

Destruction of cephalosporins

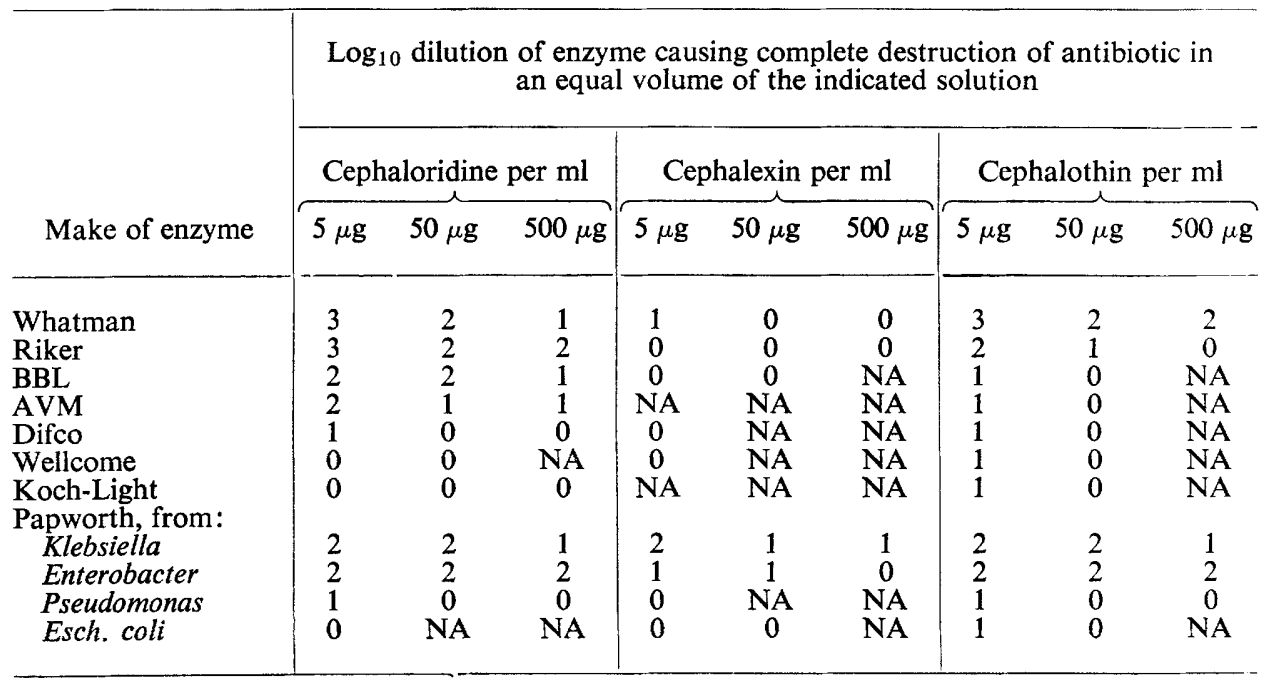

$3=$ Dilution of 1 in 1000 or more; $2=$ dilution of 1 in $100 ; 1=$ dilution of 1 in $10 ; 0=$ undiluted; $\mathrm{NA}=$ no activity.

Tests of shorter reaction times showed that 1 in 100 dilutions of all the stronger enzymes inactivated $50 \mu \mathrm{g}$ per $\mathrm{ml}$ of benzylpenicillin when equal volumes of the reagents were mixed actually in the well of the assay dish; i.e., the reaction was almost instantaneous. The sizes of zones of inhibition of B. subtilis produced by $50,40,30,20,10$, and $5 \mu \mathrm{g}$ per $\mathrm{ml}$ of streptomycin were identical with those produced by streptomycin after incubation for $1 \mathrm{hr}$ with equal volumes of cloxacillin solution $100 \mu \mathrm{g}$ per $\mathrm{ml}$ and Riker " neutrapen" diluted 1 in 100.

\section{Discussion}

A wide range of $\beta$-lactam antibiotics is now available and many of these are described as "penicillinase resistant". This term correctly describes the in-vivo situation with regard to staphylococci, but it is not surprising that it does not hold in vitro where concentrated enzyme preparations, often produced from non-pathogenic bacteria, can be used. The number of $\beta$-lactamases available was greater than might be expected and several of them destroyed 
all the antibiotics against which we tested them. The total biological activity of the stronger enzymes and the relative resistance of the substrates were not estimated precisely because the ability to destroy $500 \mu \mathrm{g}$ per $\mathrm{ml}$ is all that is relevant in the laboratory. The amount of benzylpenicillin destroyed by the commercial enzymes did tally with their makers' specifications. Nevertheless, the existence of so many ways of expressing $\beta$-lactamase activity is undesirable and an internationally acceptable unit is needed. These results confirm an earlier report (Newsom, 1967) and those of Sabath et al. (1968) and Waterworth (1972), which suggested that $\beta$-lactamases can be used to neutralise antibiotics other than benzylpenicillin for laboratory procedures. Stroy and Preston (1971) have also used an Enterobacter cloacae culture filtrate to neutralise cephalosporins, although they do not comment on its action against penicillins. This is, however, presumably a weaker enzyme than one made by cell disruption, because most of the $\beta$-lactamase produced by Enterobacter is inside the cell (Hennessey, 1967). We have used the Riker enzyme for several years to neutralise cloxacillin or cephaloridine in the serum of patients, when assaying an aminoglycoside. The enzyme activity against a stock solution of $100 \mu \mathrm{g}$ per $\mathrm{ml}$ of cloxacillin or cephaloridine is used as a control, because there have been occasional failures due to inadequate storage of the enzyme. There is also a possibility that different batches of enzyme vary in potency, for their production is a biological process.

The alternative method for assaying an aminoglycoside in the presence of a $\beta$-lactam antibiotic is to use a marker organism that is sensitive only to the aminoglycoside. Esch. coli is usually recommended, but its resistance to $\beta$-lactam antibiotics is carried on an episome and may not be stable. The destruction of the $\beta$-lactam antibiotic is probably a more reproducible method.

The home-made klebsiella and enterobacter enzymes were very simple preparations, but nevertheless they possessed more activity against the cephalosporins than did the bacillus enzymes. The strain of Klebsiella was unusual in that it was resistant to $100 \mu \mathrm{g}$ per $\mathrm{ml}$ of cephalosporin $\mathrm{C}$ and was an active producer of "cephalosporinase". A suitably purified and concentrated klebsiella extract might provide the most potent of all enzymes.

Finally the results of the timed tests with benzylpenicillin showed that a strong enzyme destroyed the antibiotic before any had time to kill the indicator organism. The technique of pre-incubation is simple to use for performing antibiotic assays, but the rapid destruction of the antibiotic would be very valuable for destroying penicillin in blood that is to be cultured.

\section{SUMMARY}

Eleven $\beta$-lactamases were tested for their ability to destroy the currently available $\beta$-lactam antibiotics. The biochemical activities of the enzymes against cephaloridine and benzylpenicillin were compared by iodometric assay. Their biological activity was tested by mixing various amounts of enzymes and of 13 different $\beta$-lactam antibiotic preparations and assaying the residual antibiotic by an agar-diffusion method, with Sarcina lutea as the test organism. 
All the enzymes destroyed $500 \mu \mathrm{g}$ per $\mathrm{ml}$ of benzylpenicillin and the more potent ones also destroyed "penicillinase-resistant" penicillins and cephalosporins. Crude enzyme extracts from a strain of Enterobacter aerogenes and of Klebsiella aerogenes compared favourably with the bacillus enzymes in their action on cephalosporins. Suitable $\beta$-lactamases can therefore be used to destroy all the available $\beta$-lactam antibiotics in specimens from patients, either in blood cultures or to allow the assay of other antibiotics in patients being treated concurrently with both.

We would like to thank Beecham Laboratories Ltd, Glaxo Ltd, and Whatman Biochemicals Ltd for supplies of reagents. This work was done with the help of a grant from the East Anglian Regional Hospital Board.

\section{REFERENCES}

Fleming, P. C., Goldner, M., AND Glass, D. G. 1963. Observations on the nature, distribution, and significance of cephalosporinase. Lancet, 1, 1399.

Grove, D. C., AND Randall, W. A. 1955. In Assay methods of antibiotics, New York, p. 14.

HARPER, G. J. 1943. Inhibition of penicillin in routine culture media. Lancet, 2, 569.

HenNessey, T. D. 1967. Inducible $\beta$-lactamase in Enterobacter. J. Gen. Microbiol., 49, 277.

JACK, G. W., AND Richmond, M. H. 1970. A comparative study of eight distinct $\beta$ lactamases synthesized by gram-negative bacteria. J. Gen. Microbiol., 61, 43.

KerSEY, R. C., IRIYE, T., MeEhaN, B. M., AND KaSPER, M. A. 1955. A kinetic assay for penicillinase and its importance in sterility testing. In Antibiotics Annual, 1954-55, New York, p. 147.

Kuwabara, S., AND Abraham, E. P. 1967. Some properties of two extracellular $\beta$-lactamases from Bacillus cereus 569/H. Biochem. J., 103, 27c.

Newsom, S. W. B. 1967. Treatment of staphylococcal endocarditis. Br. Med. J., 3, 678.

Newsom, S. W. B., Sykes, R. B., AND Richmond, M. H. 1970. Detection of a $\beta$-lactamase markedly active against carbenicillin in a strain of Pseudomonas aeruginosa. J. Bact., 101, 1079.

Perret, C. J. 1954. Iodometric assay of penicillinase. Nature, Lond., 174, 1012.

Sabath, L. D., Loder, P. B., Gerstein, Deborah A., AND Finland, M. 1968. Measurement of three antibiotics (penicillin, cephalothin and chloramphenicol) when present together in mixtures. Appl. Microbiol., 16, 877.

Stroy, S. ANN, AND Preston, D. A. 1971. Specific assay of aminoglycosidic- or polymyxintype antibiotics present in human sera in combination with cephalosporins. Appl. Microbiol., 21, 1002.

Waterworth, Pamela M. 1972. Personal communication. 